\title{
ВИКОРИСТАННЯ ІНФОРМАЦІЙНО-КОМУНІКАЦІЙНИХ ТЕХНОЛОГІЙ ТА ІНТЕРАКТИВНИХ МЕТОДІВ НАВЧАННЯ У МЕДИЧНИХ ЗАКЛАДАХ ВИЩОЇ ОСВІТИ В УМОВАХ ДИСТАНЦІЙНОГО НАВЧАННЯ
}

\author{
Тернопільський національний медичний університет імені І. Я. Горбачевського мОз України
}

PЕЗЮМЕ. Пандемія COVID-19 призвела до перебудови освітнього процесу і переходу вищих медичних навчальних закладів із традиційної на дистанційну форму навчання. Використання сучасних інформаційно-комунікаційних технологій сприяє ефективному впровадженню дистанційного навчання не лише завдяки стрімкому технологічному прогресу, покращенню якості і доступності Інтернет-мережі, а й формуванню професійно орієнтованих знань, умінь і навичок; створенню умов для самооцінки, покращення якості підготовки студента.

Мета - висвітлення використання інформаційно-комунікаційних технологій та інтерактивних методів навчання у вищих медичних навчальних закладах в умовах дистанційної форми навчання.

Матеріал і методи. У роботі використано емпіричні методи дослідження: спостереження, аналіз і узагальнення. Матеріалом дослідження був навчальний процес у Тернопільському національному медичному університеті імені І. Я. Горбачевского МОЗ України в умовах дистанційної форми навчання.

Результати. Для проведення дистанційного навчання використовують навчальну онлайн-платформу Moоdle. Вона дозволяє студентам отримувати доступ до лекцій, навчальних матеріалів, проходити тестовий контроль та підготовку до складання іспиту Крок-1, Крок-2. Використання онлайн сервісу Microsoft Teams дає можливість проводити відеолекції, заняття в режимі реального часу, забезпечує комунікацію між викладачем і студентами, проведення опитувань, диспутів, контроль самопідготовки, підвищує мотивацію підготовки до заняття, сприяє командній роботі студентів. Завдяки застосуванню інтерактивних методів навчання («мозковий штурм», дискусія, кейс-метод) у студентів розвиваються клінічне мислення, комунікативність, уміння працювати в команді, самостійність, підвищуються інтенсивність засвоєння навчального матеріалу та здатність до його аналізу. Використання сучасних інтерактивних методів навчання у вищих медичних навчальних закладах підвищує мотивацію та самостійність студентів, допомагає нівелювати негативний ефект відсутності клінічної практики студентів-медиків (спілкування із пацієнтами, розбір історії хвороби, участь у оперативних втручаннях тощо) в умовах карантинних обмежень.

КлючОвІ СлОвА: дистанційне навчання; вища медична освіта; інформаційно-комунікаційні технології; Moodle; Microsoft Teams; інтерактивні методи навчання.

Вступ. Пандемія COVID-19 спричинила перебудову в суспільстві, призвела до змін не лише в сфері охорони здоров'я, економічній, політичній сферах, а й у системі освіти. Запровадження карантину з метою зменшення поширеності інфекції та соціальне дистанціювання як єдиний дієвий метод профілактики захворювання призвели до переходу навчальних закладів, у тому числі й медичних 3ВО, на дистанційну форму навчання [1].

Дистанційне навчання - це форма організації освіти, що потребує використання сучасних інформаційно-комунікаційних технологій, які дають змогу навчатися на відстані, без особистого контакту між викладачем і студентом [2].

Використання інформаційно-комунікаційних технологій (IКT) у вищих медичних навчальних закладах сприяє ефективному проведенню дистанційного навчання, що дає змогу самостійно контролювати процес набуття фаху, планувати свою освітню активність, не потребуючи постійної допомоги викладача. Завдяки сучасним інформаційним технологіям учасники дистанційного навчання можуть отримувати і передавати інформацію через мережу Інтернет без обмежень у часі та просторі, спілкуватися і комунікувати з викладачами, брати участь в онлайн заходах (тренінгах, конференціях, операціях тощо), що забезпечує доступність і відкритість дистанційного навчання [3].

Для успішного проведення навчального процесу в дистанційній формі необхідні не лише сучасне апаратне забезпечення, безперервний доступ до високошвидкісного інтернету як викладачів, так і студентів, а й висока мотивація студентів та самостійність у навчанні. Саме тому використання інтерактивного навчання, метою якого $€$ створення комфортних умов для навчального процесу, за яких студент відчуває свою успішність, інтелектуальну спроможність, підвищує продуктивність роботи, $\epsilon$ ключовим у вирішенні даних проблем (мотивації та самостійності) [4].

Мета - висвітлення використання інформаційно-комунікаційних технологій та інтерактивних методів навчання в медичних навчальних закладах в умовах дистанційної форми навчання.

Матеріал і методи дослідження. Методами емпіричних досліджень вивчали сукупність різноманітних технологічних інструментів і ресурсів, 
Огляди літератури, оригінальні дослідження, погляд на проблему, випадок з практики, короткі повідомлення які використовуються для забезпечення процесу навчання, та створення, поширення, збереження й управління інформацією.

Результати й обговорення. Дистанційне навчання в сучасних умовах передбачає використання різноманітних засобів інформаційно-комунікаційних технологій (IKT). IKT можна визначити як сукупність різноманітних технологічних інструментів і ресурсів, що використовуються для забезпечення процесу комунікації та створення, поширення, збереження та управління інформацією [5].

Для забезпечення дистанційного навчання використовують онлайн-платформи, такі як Moodle, Google Classrom, Atutor тощо. У Тернопільському національному медичному університеті імені І. Я. Горбачевського впродовж тривалого часу активно функціонує система дистанційного навчання Moodle. Moodle (Modular Object-Oriented Dynamic Learning Environment) - безкоштовна відкрита система дистанційного навчання, яка реалізує філософію «педагогіки соціального конструктивізму» та орієнтована на взаємодії між викладачем та студентами [6]. Перевагою цієї програми $є$ iї модульність, динамічність, гнучкість, завдяки чому забезпечується безперервний доступ до лекцій, методичних розробок, матеріалів підготовки до практичних та підсумкових занять у всіх доступних форматах (текстові файли, презентації, відео, фото, тести тощо), можливість проводити поточний і підсумковий тестовий контроль рівня засвоєння знань та підготовку до складання іспитів Крок-1, Крок-2.

Специфікою навчального процесу у вищих медичних навчальних закладах $€$ безперервний контакт між студентами та викладачами на практичних заняттях, лекціях, пізніше - із хворими, участь у клінічних розглядах пацієнтів та в операціях. Саме тому комунікація студентів і викладачів у режимі реального часу є невід'ємною складовою навчання в умовах карантинних обмежень. Завдяки програмам для відеозв'язку, таким як Microsoft Teams, Zoom, Skype, Meet, забезпечується спілкування між студентами та викладачем, стають можливими проведення дискусій, опитувань, контроль самопідготовки, підвищується мотивація підготовки до заняття. Microsoft Teams дає викладачу можливість створювати календар занять, що синхронізується із всіма технічними засобами, і студенти, отримавши посилання на них, автоматично бачать їх у своїх календарях. Під час заняття можна демонструвати презентацію, відеоматеріали, необхідні документи або посилання на них, пояснювати матеріал за допомогою цифрової дошки, розбирати винесені на семінар питання, отримувати від викладача індивідуальні завдання, обговорювати помилки і можливі методи вирішення поставленої

проблеми. В межах однієї команди-групи студенти спілкуються між собою, обмінюються файлами, посиланнями, що сприяє командній роботі в умовах дистанційного навчання. За допомогою Microsoft Teams проводяться відеолекції, які не мають ліміту часу та завдяки функції запису можуть бути доступними для додаткового перегляду учасникам групи.

В умовах дистанційного навчання в вищих медичних навчальних закладах найактуальнішими інтерактивними методами $\epsilon$ : «мозковий штурм», дискусії та кейс-метод. Інтерактивні методи навчання допомагають студентам розвивати клінічне мислення, формують їх самостійність, що $є$ ключовим фактором для навчання в умовах пандемії. Змінюється роль викладача, адже тут він виступає як організатор процесу навчання, створює умови для ініціативи та активності студентів [7].

Використовуючи один з інтерактивних методів - мозковий штурм, - студенти під час онлайн заняття протягом короткого періоду часу працюють у групі над різними варіантами вирішення певної проблеми, поставленої задачі (вибору методу хірургічного лікування, призначення медикаментозного лікування тощо). Такий вид діяльності дозволяє студентам здобути такі необхідні навички як креативність, комунікативність, здатність приймати рішення, висловлювати свої думки, вміння працювати у команді.

Метод дискусії $\epsilon$ невід'ємною частиною успішного практичного заняття в умовах дистанційного освітнього процесу, адже завдяки йому не лише обговорюються підсумки роботи, а й активізується і стимулюється мислення, краще засвоюється навчальний матеріал у результаті його всебічного розумового опрацювання. Дискусія, як і інші інтерактивні методики, сприяє підвищенню мотиваційної складової навчального процесу, стимулює студентів до самостійної роботи над поданою темою, мотивує їх до додаткових пошуків інформації з даної проблеми, самоосвітіи

Особливістю кейс-методу є навчання в процесі вирішення конкретних ситуацій (вирішення кейсів). Використання цього методу дозволяє студентам-медикам в умовах дистанційної освіти застосувати свої теоретичні знання для вирішення певного практичного завдання на онлайн занятті та після нього, розвиває здатність аналізувати і структурувати необхідну інформацію, вчить уникати типових помилок при схожих ситуаціях у майбутньому і на практиці. Отримавши на занятті кейс (певну клінічну ситуацію, типову історію хвороби) студенти мають встановити діагноз «віртуальному» пацієнту (на основі зібраного анамнезу, результатів лабораторно-інструментальних до- 
Огляди літератури, оригінальні дослідження, погляд на проблему, випадок з практики, короткі повідомлення сліджень), призначати терапевтичне чи хірургічне лікування, спрогнозувати очікуваний результат лікування. На занятті обговорюються і аналізуються помилки при вирішенні кейсу із викладачем, спільно вирішуються альтернативні шляхи їх вирішення. Ця навчальна методика максимально наближена до клінічної практики, яка в умовах карантинних обмежень тимчасово недоступна для студентів, проте отримані в процесі її виконання знання і навички будуть використані на практиці при покращенні епідеміологічної ситуації і поверненні до традиційної форми навчання.

Висновки. Ефективне поєднання сучасних інформаційно-комунікаційних технологій та інтерактивних методів освіти дозволило успішно про-

водити дистанційне навчання, не зважаючи на специфіку навчального процесу в медичних навчальних закладах. Використання сучасних інтерактивних методів навчання у вищих медичних навчальних закладах підвищує мотивацію та самостійність студентів, допомагає нівелювати негативний ефект відсутності клінічної практики студентів-медиків (спілкування із пацієнтами, розбір історії хвороби, участь у оперативних втручаннях тощо) в умовах карантинних обмежень. Упровадження дистанційної форми навчання у вищих медичних навчальних закладах із використанням IКT та інтерактивних методів відкриває нові перспективи у розширенні контингенту студентів та глобалізації навчання.

\section{ЛІТЕРАТУРА}

1. Al Samaraee A. The impact of the COVID-19 pandemic on medical education / A. Al Samaraee // British Journal of Hospital Medicine. - 2020. - Vol. 81, № 7. P. 1-4. https://doi.org/10.12968/hmed.2020.0191

2. Скрипник І. М. Використання дистанційних методів навчання в медичній освіті / І. М. Скрипник, Г. С. Маслова, Н. П. Приходько [та ін.] // Проблеми безперервної медичної освіти та науки. - 2020. - № 3 (39). C. 29-32.

3. Пайкуш М. Особливості використання інформаційно-комунікаційних технологій у професійно-практичній підготовці майбутнього лікаря / М. Пайкуш // Нова педагогічна думка. - 2018. - № 2. - С. 56-60.

4. Шеховцева Т. Г. Інтерактивні методи навчання як основа мотивації студентів в умовах сучасного педагогічного процесу / Т. Г. Шеховцева, М.О.Долінна // Ак-

туальні проблеми сучасної медицини. - 2019. - Т. 19, Вип. 1.- С. 105-108.

5. Буровицька Ю. М. Інформаційно-комунікаційні технології у вищих навчальних закладах: алгоритм впровадження / Ю. М. Буровицька // Вісник Чернігівського національного педагогічного університету. Серія : Педагогічні науки. - 2016. - Вип. 133. - С. 23-26.

6. Кушнірук А. В. Використання платформ для управління електронним навчанням у закладах загальної середньої освіти [Електронний ресурс] / А. В. Кушнірук // Open educational e-environment of modern University. - 2019. - № 6. - С. 26-34. - Режим доступу: https://doi.org/10.28925/2414-0325.2019.6.2634.

7. Філоненко М. М. Методика викладання у вищій медичній школі на засадах компетентнісного підходу / М. М. Філоненко. - К., 2016. - 88 с.

\section{REFERENCES}

1. Al Samaraee, A. (2020). The impact of the COVID-19 pandemic on medical education. British Journal of Hospital Medicine, 81, 7, 1-4. https://doi.org/10.12968/ hmed.2020.0191

2. Skrypnyk, I.M., Maslova, G.S., Prykhodko, N.P., Gopko, O.F., \& Shaposhnyk, O.A. (2020). Vykorystannia dystantsiinykh metodiv navchannia $v$ medychniy osviti [Using of distance education methods in medical education]. Problemy bezperervnoi medychnoi osvity ta nauky Problems of Uninterrupted Medical Training and Science, 3 (39), 29-32 [in Ukrainian].

3. Pajkush, M. (2018). Osoblyvosti vykorystannia informaciyno-komunikaciynykh tekhnolohiy u profesiynopraktychniy pidhotovtsi maibutnioho likaria [Features of the use of information and communication technologies in the professional and practical training of future physicians]. Nova pedagogichna dumka - New Pedagogical Thought, 2, 56-60 [in Ukrainian].

4. Shexovceva, T.G., \& Dolinna, T.G. (2019). Interaktyvni metody navchannia yak osnova motyvacii studentiv v umovakh suchasnoho pedahohichnoho protsesu [Interactive teaching methods as a basis for motivating students

in the modern pedagogical process]. Aktualni problemy suchasnoyi medycyny-Actual Problems of Modern Medicine, 19 (1), 105-108 [in Ukrainian].

5. Burovyczka, Yu.M. (2016). Informaciyno-komunikaciyni tekhnolohii u vyshchykh navchalnykh zakladakh: alhorytm vprovadzhennia [Information and communication technologies in higher educational institutions: implementation algorithm]. Visnyk Chernihivskoho natsionalnoho pedahohichnoho universytetu. Seria: Pedahohichni nauky Bulletin of Chernihiv National Pedagogical University. Series: Pedagogical Sciences, 133, 23-26 [in Ukrainian].

6. Kushniruk, A.V. (2019). Vykorystannia platform dlia upravlinnia elektronnym navchanniam u zakladakh zahalnoi serednoi osvity [Use learning management system in basic secondary education]. Open Educational E-environment of Modern University, 6, 26-34 [in Ukrainian]. Retrieved from: https://doi.org/10.28925/24140325.2019.6.2634

7. Filonenko, M.M. (2016). Metodyka vykladannia u vyshchii medychnii shkoli na zasadax kompetentnisnoho pidkhodu [Methods of teaching in medical school on the basis of the competence approach]. Kyiv [in Ukrainian]. 

И ИНТЕРАКТИВНЫХ МЕТОДОВ ОБУЧЕНИЯ В МЕДИЦИНСКИХ ВУЗАХ В УСЛОВИЯХ ДИСТАНЦИОННОГО ОБУЧЕНИЯ

\author{
○Т. И. Гаргула, М. С. Гнатюк
}

Тернопольский национальный медицинский университет имени И. Я. Горбачевского МОз Украины

Пандемия COVID-19 привела к перестройке образовательного процесса и переходу высших медицинских учебных заведений с традиционной на дистанционную форму обучения. Использование современных информационно-коммуникационных технологий способствует эффективному внедрению дистанционного обучения не только благодаря стремительному технологическому прогресу, улучшению качества и доступности Интернетсети, но и формированию профессионально ориентированных знаний, умений и навыков; созданию условий для самооценки, улучшению качества подготовки студента.

Цель - освещение использования информационно-коммуникационных технологий и интерактивных методов обучения в высших медицинских заведениях в условиях дистанционной формы обучения.

Материал и методы. В работе использованы эмпирические методы исследования: наблюдение, анализ и обобщение. Материалом исследования был учебный процесс в Тернопольском национальном медицинском университете имени И. Я. Горбачевского МОЗ Украины в условиях дистанционного обучения.

Результаты. Для проведения дистанционного обучения используют учебную онлайн-платформу Moodle. Она позволяет студентам получать доступ к лекциям, учебным материалам, проходить тестовый контроль и подготовку к сдаче экзамена Крок-1, Крок-2. Использование онлайн-сервиса Microsoft Teams дает возможность проводить видеолекции, занятия в режиме реального времени, обеспечивает коммуникацию между преподавателем и студентами, проведение опросов, диспутов, контроль самоподготовки, повышает мотивацию подготовки к занятию, способствует командной работе студентов. Благодаря применению интерактивных методов обучения («мозговой штурм», дискуссия, кейс-метод) у студентов развиваются клиническое мышление, коммуникативность, умение работать в команде, самостоятельность, повышается интенсивность усвоения учебного материала и способность к его анализу. Использование современных интерактивных методов обучения в высших медицинских учебных заведениях повышает мотивацию и самостоятельность студентов, помогает нивелировать негативный эффект отсутствия клинической практики студентов-медиков (общение с пациентами, разбор истории болезни, участие в оперативных вмешательствах и пр.) в условиях карантина.

КЛЮЧЕВЫЕ СЛОВА: дистанционное обучение; высшее медицинское образование; информационно-коммуникационные технологии; Moodle; Microsoft Teams; интерактивные методы обучения.

\title{
USE OF INFORMATION AND COMMUNICATION TECHNOLOGIES AND INTERACTIVE TEACHING METHODS IN MEDICAL UNIVERSITIES IN DISTANCE LEARNING
}

\section{Horbachevsky Ternopil National Medical University}

SUMMARY. The COVID-19 pandemic has led to a restructuring of the educational process and the transition of higher medical education from traditional to distance learning. The use of modern information and communication technologies contributes to the effective implementation of distance learning not only due to rapid technological progress, improving the quality and accessibility of the Internet, but also the formation of professionally oriented knowledge, skills and abilities; creating conditions for self-assessment, improving the quality of student training.

The aim - to highlight the use of information and communication technologies and interactive teaching methods in medical schools in terms of distance learning.

Material and methods. Empirical research methods were used in the work: observation, analysis and generalization. The material of the research was the educational process at I. Horbachevsky Ternopil National Medical University .

Results. Moodle online learning platform is used for distance learning. It allows students to access lectures, study materials, take tests and prepare for the exam Step-1, Step-2. The use of the online service Microsoft Teams makes it possible to conduct video lectures, classes in real time, provides communication between teachers and students, conducting surveys, debates, self-preparation, increases motivation to prepare for classes, promotes teamwork of students. Through the use of interactive teaching methods ("brainstorming", discussion, case-method) students develop clinical thinking, communication, ability to work in a team, independence, increases the intensity of learning material and the ability to analyze it. The use of modern interactive teaching methods in medical universities increases the motivation and independence of students, helps to eliminate the negative effect of lack of clinical practice of medical students (communication with patients, history, participation in surgery, etc.) in quarantine restrictions.

KEY WORDS: distance learning, medical education, information and communication technologies, Moodle, Microsoft Teams, interactive teaching methods. 